\title{
The Information Gathering Practices of City Officials
}

\author{
Carol Ann Traut, University of South Dakota \\ Hal G. Rainey, University of Georgia
}

The pressures on city officials warrant much more research into their evaluations of the sources of information available to them. In more complex times, are they turning more to technical and professional informational supports? How does their reliance on such sources compare to their use of other sources such as the media and contacts with the public? Do mayors and city managers differ on such questions, as one might expect? Using a more elaborate set of questions about this topic than used in previous research, this survey of mayors and city managers in Florida asked them to rate the importance of the information sources they use in decision making. The results permitted comparisons of a public responsiveness model of information-use and a professional-technical model, which usually have been treated separately in previous research. Results indicate that the mayors and city managers showed marked similarities, with the vast majority concentrating on contacts with the public. Far fewer find professional and technical sources and media sources particularly useful. City managers thus showed less reliance than we expected on technical-professional sources, except for some tendencies to do so (1) more than mayors, (2) more in larger cities, and (3) more when they feel government should be less active. The study thus supports researchers who have suggested that city managers play a stronger political and public relations role than idealized conceptions of their role suggest. More importantly, it contributes some useful findings about information use by city officials and suggests important avenues for further research.

Governments in cities of all sizes face increasingly complex and difficult problems. City officials now cope with human, economic, and environmental challenges that go far beyond the traditional city government provision of basic housekeeping and police services. Former San Francisco Mayor Dianne Feinstein $(1987,12)$, in describing the range of problems faced by mayors, spoke also to the problems of city officials in general: "Mayors who once worried about clean streets now have to worry about clean air, toxic wastes, controlling development, job training, teenage pregnancy, narcotics, labor relations, and, of course, the economic viability of their cities." This paper focuses on how city officials evaluate information sources available for responding to these and other urban problems.

Management theorists have noted for some time that greater complexity and flux in environments impose greater information-processing requirements on administrators (Daft 1989). Researchers have analyzed city officials' sources of information before (e.g., Eulau 1973), but no study has used as extensive a set of questions concerning the value of diverse information sources in decisionmaking as those in this study of mayors and city managers in Florida. First, we compare the attitudes, role perceptions, and other characteristics of mayors and city managers. Then, we analyze the relationships among these factors, environmental factors, and city officials' evaluations of information sources. 
Past Research

City officials first must sort out the information most useful to them before they can handle the complexities of modern urban policy-making. In literature and practice, two models of decisionmaking have emerged to guide city officials, a public-responsiveness model and a professional-technical model. The publicresponsiveness model most conforms to normative democratic theories about what the relationship between public officials and citizens should be in a democracy. According to these theories, officials should react positively; that is, they should put the demands of citizens into effect (Schumaker and Getter 1977). This relationship between public officials and citizens serves both as an ideal and as the most realistic alternative on the local governmental level. Citizens more easily can observe the services of local government than they can the activities of national and sometimes even state governments, and they can be expected to offer wellformed critiques of these services (Yates 1978; Sharp 1982).

Decisionmaking formulated according to this model has some negative aspects, however. If urban services are largely demand driven, then following such a model can result in the stimulation of increasing demands and the creation of unrealistic expectations, which in turn lead to citizen disappointment and alienation as government comes to the end of its capabilities (Sniderman and Brody 1977; Sharp 1982). This public-responsiveness model also may cause city officials, needing citizen support and votes, to produce short-sighted, inadequate responses to complex problems (Cupps 1977).

Research also indicates that a public-responsiveness model of decisionmaking does not necessarily result in evenhanded responses. The propensity to participate in politics generally has been linked to higher socioeconomic status and the possession of both information and civic attitudes that such status provides (Verba and Nie 1972). Officials operating under a public-responsiveness model could be getting their information about citizen wants and needs from a narrow segment of the community. Although research has not indicated inequitable distributions of services, surveys have suggested public perceptions of such a bias, particularly in relation to race, and perception often carries the force of fact (Mladenka 1981; Lineberry 1977).

Interest groups also figure in the public-responsiveness model. City bureaucrats often prefer direct public and interest group contact over demands filtered through elected officials who represent a political threat to the autonomy of the bureaucracy (Greene 1982; Abney and Lauth 1985). Abney and Lauth (1985) found that a majority of city bureaucrats said that interest groups have some or a great deal of influence. Interest-group sources of information, like those from the public in general, often are biased toward the concerns of more experienced, higher-status white groups and business interests (Abney and Lauth 1985; Galaskiewicz 1981; Schumaker and Getter 1983). Interest-group influence therefore is likely to add to the potential inequitable distributions of services that 
can occur under the public-responsiveness model.

Educational programs for professional managers often espouse an alternative model, a professional-technical model. This model stresses the need for rational, systematic, and quantitative information gathering. Proponents of this second model argue that the tremendous problems facing cities have forced them to change from "low-skilled ... highly politicized operations into professionally managed organizations" and to use more analytic and quantitative methods of information-gathering (Poister and Streib 1989, 246). Information-gathering sources under such a model would include reliance on professionals in specific fields, technical evaluation techniques, and uses of professional and organizational services available outside the city.

The two models are not strictly separate in any sense. For example, one can show a great concern for public responsiveness by emphasizing the use of professional and technical supports for it -- systematic public opinion polls, compilations of citizen requests and demands, or use of expert consultants and professional ratings to inform public opinion about issues. In addition, all city officials use both approaches to some degree. That public officials act pragmatically and divide their attention between public demands and professionaltechnical sources as specific circumstances require has been well understood by researchers. In their classic studies of the representation roles played by members of Congress, Wahlke et al. (1962) and Davidson (1964) found that some members of Congress assume distinct roles -- the delegate (public-responsiveness) role or the trustee role that relies more on "expert" sources of information or professional judgment to evaluate public needs -- while a substantial number of representatives adopted a pragmatic politico role in which they altered their information-gathering practices as necessary. The major questions here, then, are how city officials value the various sources of information, and how they mix and balance their reliance on them.

The media, representing a third source of information, could be classified as part of the public-responsiveness model. The media certainly do not necessarily reflect government officials' opinions, as the literature instructing city officials on how to handle the media clearly indicates (e.g., Anderson, Newland, \& Stillman 1983; Banovetz 1984). The media also do more than merely reflect public opinion. Research indicates that the media can operate as a political force independent of either governmental officials or interest groups and the general public (Robinson 1976; Page, Shapiro, \& Dempsey 1987). However, for purposes of public decisionmaking, the quality of media information has been questioned by many writers. Since the 1970s, the trend of media activity has been to move toward attracting audiences through entertainment. The news has become superficial and slanted toward human interest stories rather than detailed analyses of public issues (Diamond 1978, 1991). In this paper, the media will be treated as a source of information separate from public or professional sources of information.

The propensity to use either the public-responsiveness model or the profes- 
sional-technical model is in part dependent upon whether one plays a more political role (e.g., is elected) or a management role (e.g., is hired for professional expertise). The very concept of the city manager's role arose from the reform movement's advocacy of full-time, nonpartisan, professionally-trained administrators to carry out the routine duties of urban governance. City managers are more likely than mayors to hold advanced degrees and to regard their positions as careers. In turn this makes them more mobile, less attached to a particular community, and therefore possibly less responsive to public input (Schellinger 1985). Their backgrounds and separation from the election process tend to push city managers toward professional-technical information sources.

Mayors in city-manager cities rarely have the legal powers and resources to make decisions single-handedly. Often chosen by fellow commission/council members rather than directly by the voters, the mayor may lack voting and veto powers, staffing and financial resources, jurisdiction over policy areas, and appointive powers (Pressman 1972). As representatives of popular will, mayors can, through their personal skills, exert great informal influence. However, this same informal power often makes them even more vulnerable and open to public and media demands.

Much evidence shows that the traditional politics-administration dichotomy does not exist for city officials in city-manager forms of city government. City managers' involvement in policy and political decision-making is well documented. For example, Kammerer, Farris, DeGrove, and Clubok (1963), in a study of Florida city managers, found that managers not only reported presenting policy preferences but believed that they should have a policymaking role. Loveridge (197l) found that California managers viewed themselves as policymakers at least in less controversial areas. While managers still tend to describe their proper role as being administrative rather than political, over time they have engaged more and more in direct citizen contacts, direct council relationships, and in policymaking (Greene 1982; Newell \& Ammons 1987). Nalbandian (1988) and others have argued that city managers increasingly have begun to act as independent agents and interact directly with groups and individual citizens. As Svara (1985) indicates, separating administrative duties from policymaking no longer is possible.

The traditional view of the mayor as a figurehead in city-manager cities also has been challenged. Although the mayor lacks both formal powers and day-today access to city activities, the mayor who so chooses can play much more than a ceremonial role. Mayors also have the resources to serve as goal setters, as liaisons and team builders, and as coordinators of city activities (Svara 1987).

While mayors in city-manager cities can exert influence by informal and ceremonial means, mayors in mayor-council cities -- especially those with a strong mayor system -- have more formal powers. With these powers come day-to-day responsibilities for administration as well as for policymaking. In a weak-mayor system, the mayor lacks administrative powers, and policymaking authority is more fragmented, as in city-manager cities. However, regardless of whether a 
mayor-council city follows a weak- or strong-mayor format, its mayor, in the absence of a full-time manager, often becomes the policy and administrative leader of city government (Adrian and Press 1977). Consequently, this study will explore differences in the information-gathering behavior of mayors in city-manager cities, mayors in mayor-council cities, and city managers.

\section{Research Questions}

Research on city officials indicates that city mayors and city managers increasingly perform the duties of both policymaking and administration. In addition, the high visibility of local government demands that officials be responsive to the public. We therefore hypothesized that both mayors and city managers would be influenced most by direct public input in decisionmaking and only secondarily by either professional-technical or media sources.

However, mayors and managers, because of their different backgrounds, educational levels, roles, and experiences, are still expected to approach the search for information in different ways. For both groups, information-seeking also will be influenced by their attitudes toward their roles and toward citizens, as well as by their personal characteristics and the characteristics of their city environment. We further hypothesized that mayors, as elected leaders, would be more likely than city managers to report that their role is to follow citizen wishes. Mayors' views also will be more reflective of the general public view that government's role should be limited.

In terms of reported importance of various information sources, city managers, because of their education and professional experience, are more likely than mayors in general to view citizens as inattentive to, and uninformed about, government activities. They also will be more likely to support a broader governmental role. Therefore, it is expected that city managers will be less likely to rely on public contact and more likely to rely on professional-technical sources of information while mayors, directly tied to the electoral process, will be much more attentive to public and media sources of information. Because they do not have the services of professional managers, especially in smaller cities, mayors in mayor-council cities are expected to evaluate professional-technical sources of information as even less important than do mayors in city-manager cities.

\section{Description of the Survey}

The data are taken from a mail survey that was sent to city officials throughout the state of Florida in 1985. The survey was part of a larger project (sponsored by the Florida League of Cities and the Institute of Government of the State University System of Florida) to study citizen and public official attitudes toward city taxes, services, and information exchanges between government and 
citizens. The data used in this analysis are responses by city mayors and city managers.

Questionnaires were mailed to city managers in all 207 city-manager cities and to mayors in all 391 Florida cities. After two mailings, there was a response rate of 36 percent for mayors (141 out of 391 ) and 67 percent for city managers (138 out of 207). Sixty-eight mayors in city-manager cities and 69 mayors in mayorcouncil cities responded. Three mayors were from cities with commission forms of government. Four-fifths of the cities in this sample had 1980 populations below twenty-five thousand people, compared to the ICMA's 1986 national figure of 85 percent of American cities with populations under 25,000 (ICMA 1987). In size, then, these cities are reflective of cities nationally. On the other hand, these Florida cities have larger Black populations than cities across the nation: one-half of the cities in the sample had Black population percentages higher than the national average of 11.8 percent.

Both the managers and the mayors were overwhelmingly white and male. Forty women, eight Blacks, and two Hispanics (14 percent, 3.5 percent, and .7 percent of the sample respectively) responded. Overall, these officials were well educated. City managers generally were better educated, with 53 percent reporting having attended graduate school or professional school beyond college, compared to only 31 percent of the mayors. Mayors in city-manager cities did not differ significantly from mayors in mayor-council cities on any of these demographic attributes.

\section{City Officials' Attitudes Toward Government, Citizens, And Relationships Between Government And Citizens}

How policy-makers gather information is very likely to be affected by their attitudes toward the public, their views toward their own roles, and their views of the role of government in general. City officials were split almost evenly on how well-informed citizens are. For example, 42 percent of these officials agreed that citizens are well-informed while 37 percent disagreed that citizens are wellinformed. On the other hand, 47 percent of these officials also felt that citizens did not pay a lot of attention to what city officials do.

Because of their different backgrounds and roles, mayors and managers might be expected to hold different attitudes toward government and citizens. However, mayors and managers differed in only two areas. ${ }^{1}$ City managers, apparently reflecting their technical training and vested interests, were significantly less likely than mayors to say that the role of government should be limited as much as possible. Fewer city managers than mayors described their own roles as simply doing what citizens want. 
City officials were asked twenty questions concerning how they get information "which is important in [their] work with the city and/or in deciding what the citizens want and need." These questions, listed in order of city officials" evaluations of the usefulness of each information source, are listed in Table 1.

\section{Table 1. Information Sources}

We are interestd in how you get information which is important in your work with the city, and/or in deciding what the citizens want and need. How much important information do you receive from [Response categories: 1. None, 2. A Little, 3. Some, 4. A lot]

Officals answering

"some" or "a lot"

1. Your personal observations of city operations in your day-to-day activities?

$95.7 \%$

2. Informal contacts in public?

$87.8 \%$

3. Official reports or briefings from city employees or department heads?

$87.0 \%$

4. Meetings or social events with social, civic, or neighborhood groups?

$83.8 \%$

5. Statements/discussions by council/commission members at council/commission meetings?

$81.7 \%$

6. Letters or telephone calls from citizens or group representatives?

$80.2 \%$

7. Contacts from influential citizens?

$77.3 \%$

8. Statements by citizens at council/commission meetings?

$66.5 \%$

9. Citizen advisory groups?

10. Professional publications or information provided by professional associations?

11. Consultants or other outside experts?

12. Systematic evaluations such as program evaluations, management reviews, audits?

13. Election results?

$47.3 \%$

14. Contacts with news reporters?

$39.9 \%$

15. News reports or editorials in newspapers?

$39.6 \%$

16. Compiled or tabulated data concerning citizen requests or complaints?

17. Public opinion polls?

18. News reports or editorials on radio?

$24.7 \%$

19. Ratings under national rating systems or by regulatory agencies or professional associations?

Officials reported using a diverse array of information sources, including informal public contacts, 'one-on-one' citizen advisory groups, employee reports, and technical sources. The limitations of describing public officials' decisionmaking behavior strictly in terms of one or the other of the two roles we have described becomes clear in the findings; the vast majority of city officials reported relying first on themselves and their own observations rather than on information received from other sources. Evidently, city officials often follow a pragmatic, politico orientation of the sort mentioned earlier, that combines or bridges aspects of the technical-professional and the public-responsiveness models. This is consistent with research on the roles of business and governmental managers, which finds that managers usually prefer to rely on personal experiences and communications, even though some managers are more likely than others to add to their personal 
experiences a reliance on technical procedures and information (Mintzberg 1989). When the evaluations of the various information sources as important are separated into "a lot" and "some" categories, city officials rate information from their own observations, informal public contacts, and city employee reports highest. In all other cases, more of ficials evaluated the sources as providing "some," rather than "a lot" of important information.

The media are not major sources of information for these people. For media sources, the highest percentage of city officials (40 percent) relied on reporter contacts and newspaper reports while television and radio reports ranked much lower (19 percent and 25 percent, respectively) as information sources. Apparently the media as the "fourth estate" are of lesser influence in local public decisionmaking although we cannot assess their influence in specific cases. Although the mass media appear to have great influence in contemporary American society, there are some explanations for the lack of media importance for official decisionmaking. Since over sixty percent of the cities in this sample have populations of under 10,000 people, many cities may lack local media such as newspapers and television stations to cover city issues and politics on a daily basis. Second, these findings support research that argues that media coverage of the news generally has become more superficial as the media focus more resources on providing entertainment. Therefore, most media coverage of local problems is likely to be limited in its value as a decisionmaking tool for city officials.

It appears that city officials find technical and professional sources of information not very important in public decisionmaking. It is true that employee reports and briefings are seen as important by 87 percent of these officials. On the other hand, rating systems, tabulated citizen data, technical tools such as program evaluations and reviews, the use of outside consultants and experts, and professional publications and information each rank as important to less than 52 percent of these officials. Despite the increasing emphasis of the last thirty years on using analytic tools, direct public contact modes of information rather than professionaltechnical ones evidently are most important to public officials.

\section{Comparing Mayor and Manager Use of Information Sources}

Since theory indicates that mayors and city managers would differ in their evaluations of the twenty information sources, difference-of-means tests were performed to discover exactly how these two groups did vary (see endnote 1). Table 2 reports comparisons of the managers and the mayors on their reported utilization of a variety of information sources. 
Table 2. Difference-of-Means Tests for Use of Information Sources by Mayors and City Managers

We are interested in how you get information which is important in your work with the city, and/or in deciding what the citizens want and need. How much important information do you receive from: [Responses: 1. None. 2. A Little. 3. Some. 4. A Lot.]

$\begin{array}{llll}N \text { of } & \text { Mean } \quad \text { Std.Dev. Std. Error } \quad \begin{array}{l}\text { t-value } \\ \text { Cases }\end{array}\end{array}$

1. Your personal observations of city operations?

$\begin{array}{llllll}\text { Mayors } & 141 & 3.6454 & .575 & .048 & -.72 \\ \begin{array}{l}\text { Managers } \\ \text { Informal contacts in public? }\end{array} & 137 & 3.6934 & .536 & .046 & (.472) \\ \begin{array}{l}\text { Mayors } \\ \text { Managers }\end{array} & 141 & 3.4326 & .720 & .061 & .70 \\ \text { Offia } & 137 & 3.3723 & .718 & .061 & (.485)\end{array}$

3. Official reports or briefings from city employees or department heads?
Mayors
$\begin{array}{lll}140 & 3.2214 & .823\end{array}$
.070
Managers
$137 \quad 3.4964 \quad .666$
.057
$-3.06$

4. Meetings or social events with social, civic, neighborhood groups?
Mayors
141
$3.2128 \quad .809$
.068
Managers
$\begin{array}{lll}137 & 3.2044 & .709\end{array}$
.061

5. Statements/discussion by council/commission members at council/ commission meetings?
Mayors
141
$3.1277 \quad .735$
.062
$-1.51$
Managers
137
$3.2628 \quad .760$
.065

6. Letters or telephone calls from citizens or group representatives?

$\begin{array}{llllll}\text { Mayors } & 141 & 3.1489 & .774 & .065 & .11 \\ \text { Managers } & 137 & 3.1387 & .769 & .066 & (.912)\end{array}$

7. Contacts from influential citizens?
Mayors
141
$2.8369 \quad .762$
.064
Managers
137
$3.0292 \quad .675$
.058

8. Statements by citizens at council/commission meetings?
Mayors
141
$2.9645 \quad .711$
.060
Managers 137
$2.7518 \quad .745$
.064
9. Citizen advisory groups?
Mayors
139
$2.6403 \quad .933$
.079
.080

2.43

10. Professional publications or information provided by professional associations?
Mayors
139
$2.4676 \quad .819$
.069
.069
11. Consultants or other outside experts?

$\begin{array}{llllll}\text { Mayors } & 139 & 2.4820 & .912 & .077 & .08 \\ \text { Managers } & 135 & 2.4741 & .771 & .066 & (.938)\end{array}$

12. Systematic evaluations such as program evaluations, management reviews, audits?

$\begin{array}{lccccc}\text { Mayors } & 140 & 2.3929 & .987 & .083 & -.83 \\ \text { Managers } & 137 & 2.4891 & .948 & .081 & (.409) \\ \text { Election results? } & & & & & \\ \begin{array}{l}\text { Mayors } \\ \text { Managers }\end{array} & 139 & 2.4681 & .930 & .078 & .97 \\ \text { Contacts with news reporters? } & 136 & 2.3603 & .916 & .079 & (.332) \\ \begin{array}{l}\text { Mayors } \\ \text { Managers }\end{array} & 141 & 2.1915 & .910 & .077 & -1.34 \\ & 135 & 2.3333 & .846 & .073 & (.184)\end{array}$


(Table 2 Continued)

\begin{tabular}{|c|c|c|c|c|}
\hline $\begin{array}{l}N \text { of } \\
\text { Cases }\end{array}$ & Mean & Std. Dev & Sid. Error & $\begin{array}{l}\text { t-value } \\
\text { (prob.) }\end{array}$ \\
\hline
\end{tabular}

15. News reports or editorials in newspapers?

$\begin{array}{lllll}\text { Mayors } & 141 & 2.3500 & .929 & .078 \\ \text { Managers } & 135 & 22222 & .789 & .068\end{array}$

Managers

135

$22222 \quad .789$

16. Compiled or tabulated data concerning citizen requests or complaints?

\begin{tabular}{|c|c|c|c|c|c|}
\hline Mayors & 139 & 2.1583 & .870 & .074 & 1.25 \\
\hline Managers & 137 & 2.2190 & .935 & .080 & $(.211)$ \\
\hline \multicolumn{6}{|c|}{ Public opinion polls? } \\
\hline Mayors & 138 & 1.8623 & .889 & .076 & .04 \\
\hline Managers & 134 & 1.8582 & .877 & .076 & $(.969)$ \\
\hline \multicolumn{6}{|c|}{ News reports or editorial comments on radio? } \\
\hline Mayors & 139 & 1.9281 & .930 & .079 & 1.70 \\
\hline Managers & 136 & 1.7500 & .805 & .069 & $(.09$ \\
\hline
\end{tabular}

19. Ratings under national rating systems or by regulatory agencies or professional Associations?

$\begin{array}{llllll}\text { Mayors } & 136 & 1.6397 & .832 & .071 & -2.04 \\ \text { Managers } & 136 & 1.8456 & .833 & .071 & (.042)\end{array}$

20. News reports or editorial comments on television?

$\begin{array}{llllll}\text { Mayors } & 140 & 1.8857 & .898 & .076 & 2.88 \\ \text { Managers } & 137 & 1.6058 & .711 & .061 & (.004)\end{array}$

In contrast to theory, the two groups are for the most part more alike than different. Probably reflective of their direct dependence on public support, mayors were indeed more likely than managers to cite statements by citizens at meetings, television reports, and editorial comments as important sources of information. Managers, more frequently than mayors, cited the importance of ratings by ratings systems and official reports by city employees. One interesting difference between managers and mayors is that managers are significantly more likely to report influential citizens as an information source. Possibly the nature of the public's communication with government is such that "influentials" are bypassing parttime, elected generalists and directly pressuring the full-time city managers who are likely to have greater expertise and more detailed knowledge of city operations. This could well serve as an important cause of the increasingly political roles of city managers.

Another equally interesting finding is that city managers do not differ significantly from mayors in reliance on informal contacts and on meetings or social events with various community groups. This finding supports suggestions by other researchers that managers often play as much of a political and expository role as do mayors in contemporary urban environments.

\section{Mayors in City-Manager and Mayor-Council Cities}


only three of the information sources. Almost 93 percent of mayors in citymanager cities, compared to 55.5 percent of mayors in mayor-council cities, reported receiving "some" or "a lot" of information from meetings or social events with social, civic, or neighborhood groups. Seventy-six percent of mayors in citymanager cities, compared to 54.4 percent of mayors in mayor-council cities, received "some" or "a lot" of information from citizen advisory groups. Finally, 62 percent of mayors in city manager cities, compared to 44 percent of mayors in mayor-council cities, claimed that consultants and outside experts provided "some" or "a lot" of information.

Given the sample size and lack of explanatory variables in the data, we can only speculate about the differences between the two groups on these sources. Both citizen advisory groups and consultants and outside experts are management tools often used in the "professionalized" city-manager form of government and not so closely identified with the traditionally more "politicized" environment of mayorcouncil cities. However, contrary to expectations, mayors in city-manager cities also showed a greater preference for meetings with various citizens' groups. Certainly, more research is needed to understand how the different city government forms under varying circumstances (e.g., election years, city size and resources, weak- versus strong-mayor governments) might affect mayors' choices of information. From this point forward, this analysis will combine all mayors into one group.

\section{Information Source Modes}

After individual sources of information and their uses by city managers and mayors were examined, general categories of information sources were created to examine the factors leading to city-official preference for public-responsiveness, professional-technical, and media sources of information. Correlations among the twenty information source variables indicated that three modes exist. These variables fit together theoretically and statistically.

Public sources of information include informal and citizen-initiated contacts with government: informal contacts (q.2), meetings with groups (q.4), letters/ telephone calls (q.6), and contacts from influential citizens (q.7). Technical/ professional sources range from city employee reports (q.3) and ratings (q.19) to evaluations (q.12), use of consultants (q.11), and professional publications/ information (q.10). Media sources include reports in newspapers (q.15) and on television (q.20) and radio (q.18), and contacts with reporters (q.14). Additive indexes were created with ranges in values from 4 to 16 (public sources, media sources) and 5 to 20 (professional-technical sources). The individual items present consistent scales internally. The Cronbach alpha coefficients for the three indexes are .69 for public sources, .83 for media sources, and .67 for professional-technical sources. ${ }^{2}$

Comparison of mayors' and city managers' respective evaluations of the three types of information sources discloses that there is no statistically significant 
difference in how each group ranks these sources. Although (as expected) managers tended to place more emphasis on the importance of professional/ technical sources while mayors relied more on the media, these differences could have occurred by chance.

Managers, contrary to expectations, are not significantly more likely to use professional-technical sources, nor are they more likely to ignore the informal and personal means of citizen input. These results tend to support suggestions by some researchers (e.g., Nalbandian 1988; Newell \& Ammons 1987) that the dichotomous "traditional politics/administration" theory of the relationship between elected of ficials and managers bears little resemblance to the actual roles played by mayors and city managers.

\section{Multivariate Explanations of Rankings of Information Sources}

Whether the respondent was a mayor or a city manager did not explain completely how city officials evaluated these information-source categories. Other variables need to be taken into account in explaining city officials' evaluations of sources of information. Demographic characteristics such as the level of education and length of service can influence the use of certain categories of information, as can attitudes. ${ }^{3}$ Officials who feel that citizens are not very competent, that the role of government should be expanded, and that an official's role is to go ahead with the right decision with or without public approval might be more likely to consider professional/technical sources as important. Those who feel that government should be limited and that their own role is to do what citizens want might be more likely to see the public as an important information source.

City characteristics also may affect rankings of information sources. Professional-technical sources may figure more importantly in larger cities that have more highly developed administrative components. Finally, higher levels of group demands and intergroup conflict may cause city officials to regard public and media sources of information as more important. The percentage of Blacks in a city makes a good measure of intergroup conflict because they are a significant group in Florida, and in the South in general. Also, previous research has indicated that Blacks perceive city government actions differently (and often more negatively) than do whites (Brown and Coulter 1983; Lineberry 1977).

OLS regression models were run for each of the information-source modes using the following independent variables: mayor or manager, with manager coded $1(M G R)$; years of education (EDUC); years in office/post (YEARS); size of city (CITY); percent Black population (BLACK); officials' evaluations of citizen competence (COMP); officials' belief in an expanded governmental role, coded as 1 (GOVT); officials' beliefs about the necessity for responsiveness -- "My role is to do what citizens want" -- with the negative responses coded higher (ROLE); and managers who advocate an expanded governmental role (GOVTMGR). Table 3 shows the results of this analysis. 
Table 3. Demographic, Attitudinal, and Ecological Explanations of Information-Source Preference: Regression Results (Betas)

\begin{tabular}{lccc}
\hline & Public & Prof-Tech & Media \\
MGR & -.01 & $.46^{*}$ & -.09 \\
EDUC & .04 & .03 & .02 \\
YEARS & -.03 & -.05 & .01 \\
CITY & .07 & $.13^{*}$ & .11 \\
BLACK & -.02 & $-.20^{*}$ & -.11 \\
COMP & .11 & $.12^{*}$ & $.13^{*}$ \\
GOVT & -.03 & $.19^{*}$ & $.11^{*}$ \\
ROLE & -.06 & .01 & .06 \\
GOVTMGR & - & $-.43^{*}$ & - \\
& $\mathrm{F}=.61$ & $\mathrm{~F}=2.82$ & $\mathrm{~F}=1.81$ \\
& $\mathrm{p}=.77$ & $\mathrm{p}=.004$ & $\mathrm{p}=.08$ \\
& $\mathrm{R}^{2}=.02$ & $\mathrm{R}^{2}=.11$ & $\mathrm{p}=.06$ \\
\hline
\end{tabular}

*Significant at .05 level (one-tailed test)

Even though the models explain relatively little of the variation in evaluations of each information source, one of the three models (professional-technical sources) is significant at the .05 level and another (media sources) at the .10 level. Educational level (EDUC), years in position (YEARS), and the beliefs of city officials concerning their own roles (ROLE) have no meaningful effect on evaluations of information sources since the coefficients for these variables are near zero and the probability values are high. Officials' attitudes toward citizen competence (COMP), contrary to what might be expected, have a positive effect for all information sources, although they are not statistically significant in the case of public sources.

Official position (MGR). As expected, city managers are significantly more likely than are mayors to evaluate professional-technical sources of information (PROF-TECH) highly. When controlling for other variables, the two groups do not differ significantly in their evaluations of the media and public contacts although, in this sample, mayors are more likely to evaluate these sources positively.

Beliefs about role of government (GOVT). City officials who support an expanded government are more likely to evaluate professional-technical sources and media sources as useful. Secondly, although the findings are not significant, officials who believe in an expanded government view public input sources as less useful sources of information.

Size of city (CITY). There is a positive relationship between city size and positive evaluations of professional technical sources by city officials. Larger cities can be expected to have more resources and expertise available to be utilized by city officials. The size of the city did not affect officials' use of public input. 
Clearly, city size is not by itself a proxy for the presence of conflict that might increase official attention to direct public input. The size of the city had no significant effect on official evaluations of the usefulness of media sources.

Percentage of Blacks in population (BLACK). The percentage of blacks in a city's population represents potential for both conflict and for increased group demands. Officials in cities with larger black populations are less likely to pay attention to professional-technical sources of information and media sources (although this latter result is not statistically significant). Interestingly, the presence of a larger black population shows no relation to city officials' attention to public input.

Interaction term (GOVTMGR). It is quite possible that the effects of the independent variables may be different for mayors and managers. To determine if this is the case, interaction terms were created by using the product of each independent variable and the dummy variable for manager. There is one model in which an interaction term using the manager dummy variable and attitude toward governmental role generates meaningful and interesting results.

Managers generally were more likely than mayors to rely on professionaltechnical sources of information. However, managers who supported a larger governmental role evaluated these professional-technical sources of information as less important. Managers' beliefs in expanded governmental roles appear to alter traditional expectations of manager attitudes. Such beliefs may indicate support for a more politicized role for city managers, in which managers directly seek out citizen demands rather than relying on elected officials for policy direction.

\section{Conclusion}

The literature indicates a distinction between a public responsiveness model and a public management/professional-technical model. These two frameworks are open to challenge. Actually, many mayors now have professional and educational backgrounds which may incline them toward professional-technical information sources. City managers also play political roles. The distinction between the two frameworks bears on more general questions about city officials' orientations toward professional-technical information and decision supports that are increasingly available to all officials in government. Note, in this regard, that the public-responsiveness model represents the intent to be responsive, rather than the achievement of it. Officials may try to get public input through relatively unsystematic, and thus unrepresentative means, rather than through technologically-advanced communication processes. In addition, public input may be quite limited as a means of solving complex technical problems and policy dilemmas. We also can anticipate that further research in specific policy areas would reveal that city officials' choices of information will vary according to the issue area being addressed. 
The original expectations about the differences between the orientations of mayors and city managers were supported to some degree. The mayors were more likely to agree that the role of government should be limited and more likely to say that their own role was to do what the citizens want. In rating information sources, the mayors reported paying more attention to statements at city council meetings and to news reports while the managers were more attentive to official reports and staff briefings and to national rating systems. When the information sources were aggregated into three categories, and regressed on the set of demographic, attitudinal, and city ecological variables, the results indicated that the city managers were more attentive to professional-technical sources of information. The general distinction of mayor as politician, manager as professional, held to this extent. Media sources, at least in smaller cities without such resources, did not play a major role.

Yet other results suggest a more complex picture. City managers reported receiving more information from contacts with influential citizens than did mayors. Also, when we entered the interaction term (which represented city managers who supported expansion of government activities) into the regressions, these city managers reported less attention to professional-technical sources. These results need some further analysis, but they suggest that many of the city managers may play a greater political role than suggested by the general findings above, at least incertain ways. They actively may seek out contacts with influential citizens, or those citizens may contact them, recognizing their relative permanence and administrative importance. The results for the interaction term suggest that city managers who support expanded government fall out of the professionaltechnical orientation and move toward reliance on public input. This, too, indicates a somewhat more political or public-responsiveness orientation on the part of many managers. Managers may interpret an active role of government as one requiring that they stay in close touch with what the officials and active citizens say they want and will support. Whatever the interpretation, the finding suggests complexities that underlie the broad distinctions between the two frameworks, and raises interesting questions for further inquiry about when and how city officials mix and move between the two general models.

This study has indicated the overall importance of the public-responsiveness model. The differences between the mayors and city managers were rather small. The groups essentially concurred on almost everything, and especially on the relative dominance of information from informal contacts in public, meetings or social events with groups, discussions at council meetings, letters or phone calls, personal observations of city operations, and contacts from influential citizens. In contrast, the more systematic, professional, and technical sources of information received less attention. We know that these two models can overlap and blend together in many ways. It appears that it would be useful to achieve more balance and mutual supportiveness between the two models. Some of the regression resuits offer support for the view that using more technical-professional sources 
would be desirable. Officials from larger cities reported giving more attention to such sources of information, which suggests that larger cities with more administrative resources employed them more -- i.e., those who could afford them used them. Officials in cities with higher percentages of Blacks in their populations reported less reliance on professional-technical sources and compiled data. This may happen because these cities are poorer and cannot afford such supports. On the other hand, this may indicate that such cities also have more group conflicts and demands to resolve, which have the effect of politicizing, rather than rationalizing, the decision process. In such a decision environment, emphasis on direct contacts with the public and active groups, rather than on professional sources of information, is necessary to the political survival of city officials.

One troublesome possibility is that question-wording may have prompted responses concerned with citizen input. The key question about information sources ends with a reference to the wants and needs of citizens. Perhaps this increased their tendency to mention contacts with citizens and other public contact. We made the point earlier that systematic techniques could be used to find out what citizens need and want. However, in this survey, city officials ranked such techniques as survey research and tabulations of citizen requests very low (see Table 2). One can argue that accidental contacts in public, social gatherings, and even city council meetings that city officials do report as important often misrepresent the interests and preferences of the broader public. This is one of the standard critiques of pluralism and liberalism. Even if the question skews the emphasis toward citizen wants and needs, then, we feel the point still stands that the city officials do not make extensive use of the professional and technical sources potentially available.

The possibility of question-wording effects brings up important issues for future research. City officials certainly must use different sources of information for different purposes and under different circumstances. For example, they probably use public contacts for information about highly visible issues directly affecting the public, and turn to more technical sources (where available) as needed for more technical issues. Additional research can attempt to distinguish types and domains of decisionmaking and the information use associated with each. In defense of the method we have used, however, notice how demanding it will be to devise research methods and concepts for use in such research. More research into the behaviors associated with information gathering and utilization, as well as surveys and more intensive qualitative investigation of city officials' information-search, information-processing, and utilization behavior, should prove valuable.

The discussion of technical versus responsiveness orientations raises some of the classic questions about democratic governance, including the representative roles of public officials, the roles of active groups and individuals as opposed to those of the general public, and other democratic issues too complicated to discuss here. More generally, these findings suggest the value of more discussion of whether information-and decision-supports for urban officials should be enhanced 
to increase their skills in using a variety of information sources.

\section{NOTES}

'In this and other comparisons of groups, difference-of-means tests rather than nonparametric tests were used to examine differences between groups. Although the data are ordinal, the former statistics are familiar to more readers. The results are the same using the Mann-Whitney U test.

${ }^{2}$ The professional-technical index has a different range of values from those of the other two indexes and that range difference might affect the results. Therefore, we ran altemative analyses using $\mathrm{z}$-score transformations of the individual variables in order to produce a standardized range of values. There were no differences between the outcomes of the regression analyses using $z$-score transformations and those using the original indexes. Therefore, the results with the original values are presented.

${ }^{3}$ While gender and race of the city official are also possible explanations for evaluations of the usefulness of various information sources, they are not included as independent variables. Race is not included because, in this study, there were too few Blacks (eight overall) to make meaningful comparisons. There also were relatively few women in this study (40), and there was no reason to think that female and male public officials differ in terms of what information sources they use.

${ }^{4}$ Political party membership and political ideology are classic variables used to explain other attitudes and behaviors. However, there are no clear-cut hypotheses concerning these variables and evaluations of information sources. Bivariate correlations indicated that these two variables had no effect in explaining city official attitudes toward the various information sources. These variables, then, are excluded from OLS regression analyses.

\section{REFERENCES}

Abney, Glenn and Thomas Lauth. 1985. Interest-Group Influence in City Policymaking: The View of Administrators. Western Politics Quarterly 38:7-29.

Adrian, Charles R. and Charles Press. 1977. Governing Urban America, 5 th ed. New York: McGraw-Hill.

Anderson, Wayne E., Chester A. Newland, and Richard J. Stillman, eds. 1983. The Effective Local Government Manager. Washington, DC: ICMA.

Banovetz, James. 1984. Communicating with the Public. In James B anovetz, ed., Small Cities and Counties: A Guide to Managing Services. Washington, DC: ICMA.

Brown, Karin and Philip B. Coulter. 1983. Subjective and Objective Measures of Police Service Delivery. Public Administration Review 43: 50-58.

Cupps, D. Stephen. 1977. Emerging Problems of Citizen Participation. Public Administration Review 37: 478-487.

Daft, Richard L. 1989. Organization Theory and Design. St. Paul, MN: West.

Davidson, Roger. 1969. The Role of the Congressman. New York: Pegasus.

Diamond, Edwin. 1978. Good News, Bad News. Cambridge, MA: MIT Press. 
1991. The Media Show: The Changing Face of the News, 1985-1990. Cambridge, MA: MIT Press.

Eulau, Heinz and Kenneth Prewitt. 1973. Labyrinths of Democracy. Indianapolis: BobbsMerrill.

Feinstein, Dianne. 1987. Who are the Nation's Busiest Executives: Mayors. City and State (Nov.): 12-13.

Galaskiewicz, Joseph. 1981. Interest Group Politics from a Comparative Perspective. Urban Affairs Quarterly 16: 259-280.

Greene, Kenneth R. 1982. Municipal Administrators' Receptivity to Citizens' and Elected Officials' Contacts. Public Administration Review 42: 346-354.

International City Manager Association (ICMA). 1987. ICMA Municipal Year Book, 1986. Washington, DC: ICMA.

Kammerer, Gladys, Charles Farris, John DeGrove, and Alfred Clubok. 1963. The Urban Political Community. Boston: Houghton-Mifflin.

Lineberry, Robert L. 1977. Equality and Urban Policy. Beverly Hills: Sage.

Loveridge, Ronald O. 1971. City Managers in Legislative Politics. Indianapolis: BobbsMerrill.

Mintzberg, Henry. 1989. Mintzberg on Management. New York: Free Press.

Mladenka, Kenneth R. 1981. Citizen Demands and Urban Services: The Distribution of Bureaucratic Response in Chicago and Houston. American Journal of Political Science 25: 693-714.

Nalbandian, John. 1988. Local Government Professionals Under Stress: In Pursuit of Economic Development, Efficiency, and Equity. Public Administration Review 48: 588-591.

Newell, Charldean and David N. Ammons. 1987. Role Emphases of City Managers and Other Municipal Executives. Public Administration Review 47: 246-253.

Page, Benjamin I., Robert Shapiro, and Glenn R. Dempsey. 1987. What Moves Public Opinion? American Political Science Review 81: 23-43.

Poister, Theodore H. and Gregory Streib. 1989. Management Tools in Municipal Government; Trends Over the Past Decade. Public Administration Review 49: 240-248.

Pressman, Jeffrey. 1972. Preconditions of Mayoral Leadership. American Political Science Review 66: 511-524.

Robinson, Michael J. 1976. Public Affairs Television and the Growth of Political Malaise. American Political Science Review 70: 409-432.

Schellinger, Mary A. 1985. Local Government Professionals Under Stress: In Pursuit of Economic Development, Efficiency, and Equity. Public Administration Review 45: 246-253.

Schumaker, Paul D. and Russell W. Getter. 1977. Responsiveness Bias in 51 American Communities. American Journal of Political Science 21: 247-281.

- 1983. Structural Sources of Unequal Responsiveness to Group Demands in American Cities. Western Political Quarterly 36: 7-29.

Sharp, Elaine B. 1982. Citizen-Initiated Contacting of Government Officials and Socioeconomic Status: Determining the Relationship and Accounting for It. American Political Science Review 76: 109-115.

Sniderman, Paul and Richard Brody. 1977. Coping: The Ethic of Self-Reliance. American Journal of Political Science 21: 501-521. 
Svara, James H. 1985. The Complementary Roles of Officials in Council-Manager Government. ICMA Municipal Year Book. Washington, DC: ICMA.

1987. Mayoral Leadership in Council-Manager Cities: Preconditions Versus Preconceptions. Journal of Politics 49: 207-227.

Verba, Sidney and Norman Nie. 1972. Participation in America: Political Democracy and Social Equality. New York: Harper.

Wahlke, John C., Heinz Eulau, William Buchanan, and LeRoy C. Ferguson. 1960. The Legislative System: Explorations in Legislative Behavior. New York: Wiley. Yates, Douglas. 1978. The Ungovernable City. Cambridge, MA: MIT Press. 